\title{
Transport Patterns of Tropical ReEF Fish LARVAE BY SPIN-OfF EDDIES IN THE STRAITS OF FLORIDA
}

\author{
By Hans C. Graber and Claire B. Limouzy-Paris
}

\section{$B_{\text {etter description of }}$}

transport patterns...

is essential for under-

standing the relation-

ship between replen-

ishment of larvae and

their subsequent set-

tlement at sites . . .
$\mathrm{T}$ ROPICAL REEF FISHES belong to a broad phylogenetic group and, as a result, exhibit considerable diversity. Their only shared characteristic as an ecological entity is their fate as reef-associated adults. Their complex life cycles, in which pelagic larval phases alternate with demersal juvenile and adult phases, varies considerably within the early life history (ELH) stages (i.e., egg, larval, and juvenile stages) (Cowen and Sponaugle, 1997). This variability implies coral reef fishes have adapted differentially to the surrounding dynamic environment and may utilize different pathways while in the pelagic zone, to be transported nearshore at the time they metamorphose. Better description of transport patterns (e.g., dispersal and retention mechanisms) is essential for understanding the relationship between replenishment of larvae and their subsequent settlement at sites where transition into juveniles and adults can be achieved.

Recent large-scale ichthyoplankton and hydrographic surveys in the southern Straits of Florida have suggested that mesoscale circulation processes (i.e., cold core gyres) induce significant recruitment variability of reef fish and lobster larvae along the Florida Keys (Yeung, 1991; Lee et al., 1992, 1994). These gyres of relatively long duration (1-3 mo) often cause shoreward transport and tend to concentrate and retain locally spawned larvae (Porch, 1993; Lee et al., 1994; Criales and Lee, 1995). However, in a nongyre situation, less is known about the dynamics of coastal interactions between the strong frontal boundary of the meandering Florida Current (FC) and the inshore reef system. Numerous researchers have speculated that hydrographic features serve to retain larvae near their spawning sites on the reefs (Leis, 1993; Milicich, 1994; Richards et al., 1995). Cowen et al., (1993) further suggested that dynamic oceanic processes in

Hans C. Graber, Rosenstiel School of Marine and Atmospheric Science, University of Miami. Miami, FL 33149-1098. USA: Claire B. Limouzy-Paris, Marine Sciences Research Center, State University of New York at Stony Brook, NY 11794-5000, USA. conjunction with specific behavior patterns may be involved in translocation of diverse reef fish assemblages and specific-level biota. Thus small-scale flow measurements are needed to characterize these mechanisms acting upon the ELH stages.

Here we report on observations of reef fish larval transport mediated by remotely sensed spin-off eddies. Such eddies were first observed by Lee (1975) in current meter data. However, remote sensing of currents using $\mathrm{HF}$ radar provides a unique tool to probe repeatedly and noninvasively the ocean surface at high spatial and temporal resolution over a large domain.

\section{Biological Sampling and Current Observations}

An ichthyoplankton survey was carried out with the R/V Oregon II during the 13 -h period from 1300 UTC 25 May to 0330 UTC 26 May 1994. The survey consisted of nine stations ( 7 day and 2 night) along three transects (Figure 1) with 23 hauls sampled via oblique tows using Bongo nets with a 333- $\mu \mathrm{m}$ mesh. Expendable bathythermographs were deployed before each haul to determine the depth of the thermocline. The results discussed here are limited to surface samples (0-40 $\mathrm{m}$ ) that were always within the mixed layer. Details of the biological analysis can be found in Limouzy-Paris et al. (1997).

The OSCR system measured the surface vector current fields associated with coastal eddies over the coral reefs and the adjacent FC. From two sites located at Boca Chica and Bahia Honda in the South Florida Keys, currents were recorded in near real time (20-min sampling) and at $1-\mathrm{km}$ resolution over a $30 \times 40-\mathrm{km}$ domain.

Average surface current maps were computed for each biological transect to represent mean reef and oceanic flow conditions. Horizontal trajectories were computed at 20-min intervals for $12 \mathrm{~h}$ before (backward) and after (forward) each station was sampled. In these calculations we assume no mixing or external forces (winds and waves) influenced the trajectories. These trajectories were used to estimate the origination and destination of reef fish larvae. 


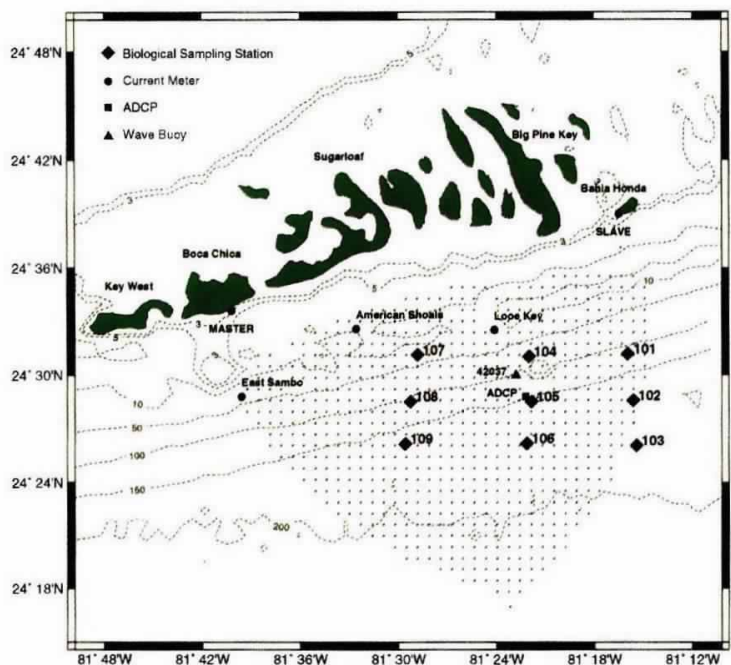

Fig. 1: Experimental setting in the lower South Florida Keys. The small dots show the OSCR cell positions.

\section{Eddy Dynamics}

During the 13-h synoptic sampling period a cyclonic spin-off eddy, $10 \mathrm{~km}$ in diameter, with a swirl speed of $\approx 50 \mathrm{~cm} \mathrm{~s}^{-1}$, migrated along the inshore edge of the meandering FC. It had an eastward translation speed of about $25 \mathrm{~km} / \mathrm{d}$ (see Fig. 1 in Haus et al., 1997). This feature produced a strong cyclonic current reversal and westward flow of $20-30 \mathrm{~cm} \mathrm{~s}^{-1}$ in the upper $50 \mathrm{~m}$ (above the thermocline) at a mooring equipped with an acoustic Doppler current profiler (ADCP) offshore of Looe Reef. Shay et al., (1997) compared OSCR surface current vectors with the upper most bin ( $15 \mathrm{~m}$ below surface) of the ADCP and found very high correlation $(>0.8)$ during this sampling period. The vertical distribution of the horizontal

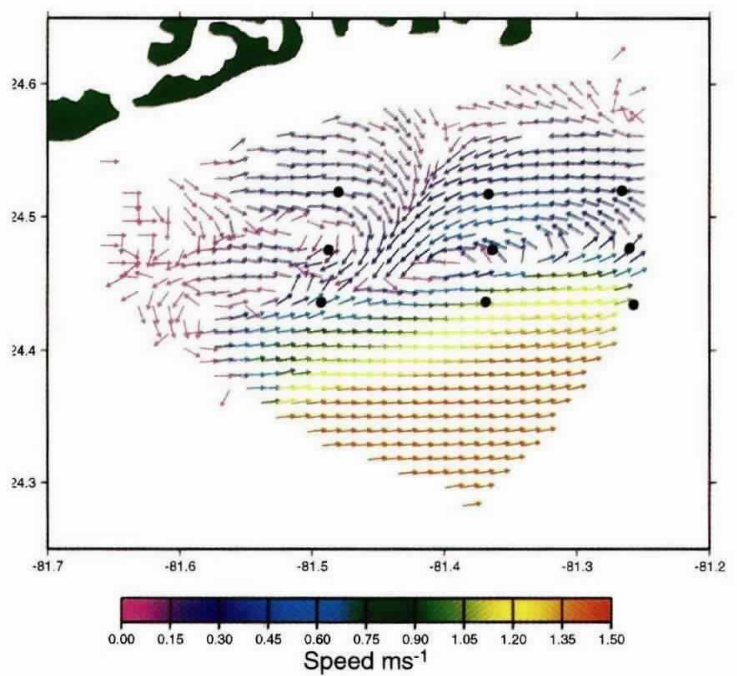

Fig. 2: Average surface vector currents observed by OSCR during the sampling period of the easternmost transect (Stations 101-103). The dots (•) indicate biological sampling stations as defined in Figure 1. flow was uniform during this period, suggesting little shear in the upper ocean layer above the thermocline. The presence of the eddies was also observed in the subsurface temperature field that showed distinct doming of the $27^{\circ} \mathrm{C}$ isotherm surface (Graber et al., 1995) that extended to a depth of 50-75 m.

The following flow patterns were observed during the survey of the eastern transect (101-103); these stations sat on the eastern edge of a well-defined eddy causing strong onshore flow (Fig. 2). At the western end of this feature (between the middle and western transects) a strong alongshore flow convergence and offshore jet was observed. In the wake of this eddy, a weak, less-defined eddy formed in the western part of the OSCR array. The dominant FC initially intruded far reefward.

The temporal coverage of the OSCR data showed how these features evolved during the survey. During the middle transect (104-106) the main eddy advected eastward and moved partially out of the domain, producing a weak convergence near the reefward stations. The offshore station was then located on the boundary of the stronger (>1 $\mathrm{m} \mathrm{s}^{-1}$ ), eastward flowing FC. A weak trailing disturbance was observed near the western transect. By the time stations 107-109 were sampled, the main eddy feature had totally vanished from the OSCR domain and the FC had moved further offshore. For the biological analysis these flow scenarios were related to the micro-distribution and abundance of larval fishes.

\section{Ichthyoplankton}

Results from the 13-h sampling period were representative of the very high biodiversity previously observed in the Florida Straits (LimouzyParis, 1994). More than 5,000 fish larvae, representing 246 taxa, were collected. The dominant taxa $(61 \%)$ were reef fishes. Abundance and distributions were determined for reef, coastal, and oceanic groups. Limouzy-Paris et al., (1997) compared larval fish assemblages over the entire water column to the upper strata; their results indicated the importance of eddies as a mechanism for alongshore dispersal of posthatch larvae and for translocation of late stage reef fish larvae to inshore settlement sites.

\section{Trajectories}

The hypothesis of translocation and longshore dispersal was evaluated by simulating horizontal transport with particle trajectories through each station, using the ocean surface current vectors recorded during the experiment. Figure 3 shows three examples of trajectories passing through positions near selected stations. The trajectories reveal that station 102, at the inshore edge of the FC, was strongly influenced by the passage of the eddy. Water, originating in the FC, was entrained by the eddy and transported onshore and westward (Fig.
. . . a cyclonic spin-

off eddy . . .

migrated along the

inshore edge of the

meandering FC. 

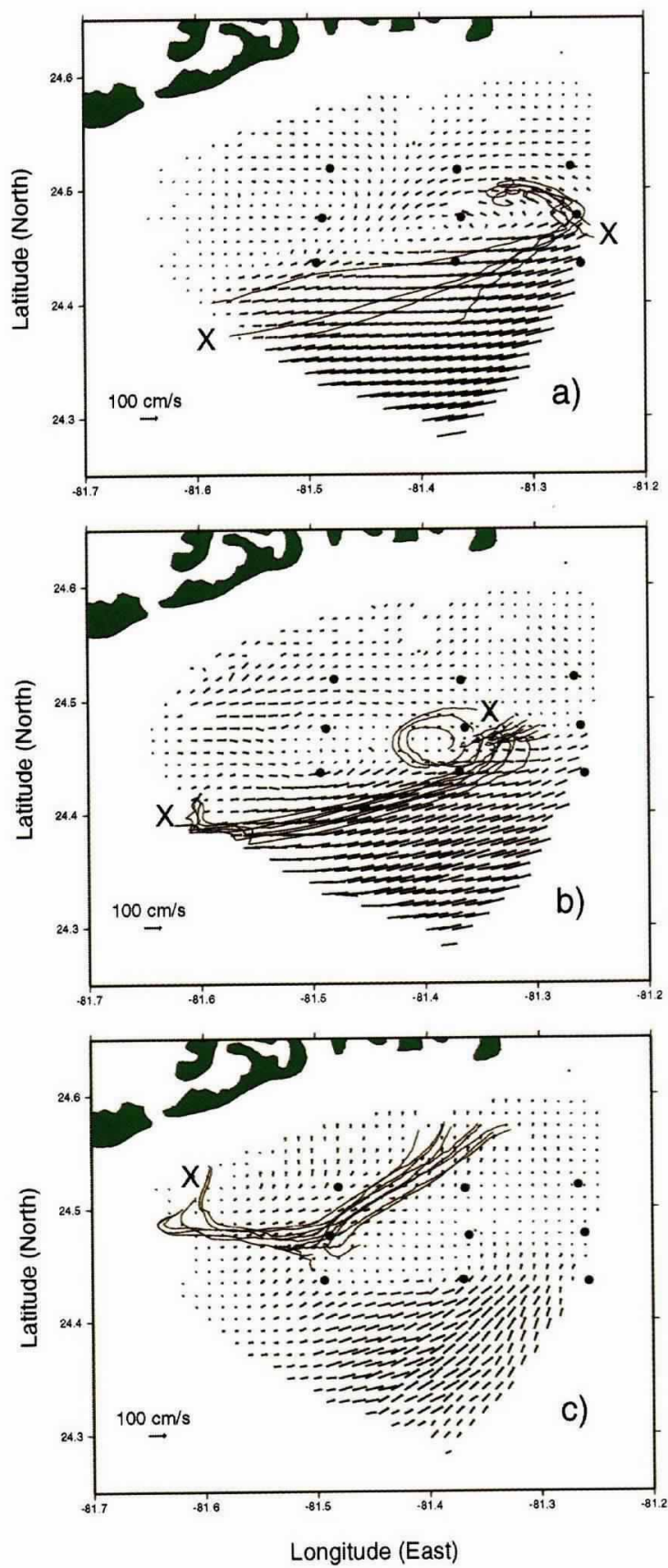

Fig. 3: The trajectories represent the simulated transport patterns of fish larvae when treated as passive particles. The surface current maps in each panel corresponds to the flow field at the sampling time, $T_{0}$, of the selected station. A cluster of trajectories from the nine OSCR cells surrounding a station were computed for a period of $12 \mathrm{~h}$ before and after the sampling time. $\times$, start of each trajectory bundle (i.e., $T_{0}-12$ ).

spective on larval

ecology but also a vi-

able approach to di-

rect biological sam-

pling . . . transect at station 108 (Fig. 3c), the trajectories showed purely coastal origin, with possible tidal influence, moving slower but in the same direction (alongshore) as the main eastward flowing FC.

\section{Translocation}

Results from the upper 40-m samples strongly suggest species specific distributions were largely influenced by the dynamics of eddies. As a response to the eddy effect, representative species of each ecological grouping (i.e., reef, coastal, and oceanic) showed anomalies in regard to their distribution across the strong FC frontal boundary. The displacement of oceanic tuna larvae (Thunnus sp.) toward shore in the middle transect in the convergence zone suggests that eddy dynamics allowed cross-frontal exchanges, translocating larvae shoreward (Fig. 4a). Most coral reef species spawn pelagic eggs; these eggs and newly hatched larvae move passively through the water column. They could be entrained from upstream locations in the FC front, having distributions more like larvae of oceanic fishes than reef fishes (Leis, 1993). Larvae from squirrelfishes (Holocentrus sp.) behaved in the same way as tuna larvae and were translocated shoreward by the spin-off eddy (not shown).

The spawning behavior of nonreef shorefishes (i.e., coastal group) in tropical areas is less understood. They apparently migrate to the shelf edge to spawn (Leis and Reader, 1991). Tonguefish (Symphurus sp.) larvae representative of the coastal group were distributed further from shore than the tuna larvae, with highest abundance in the convergence zone of the main eddy (Fig. 4b).

The spin-off eddies could also contribute to alongshore dispersal of shore fishes which spawn on the reef zone. Lower swirl speeds on the inshore edge of the eddy compared to its offshore edge could possibly trap early larvae. The simulated trajectories agree well with these biological interpretations; Figure 4 depicts the influence of eddies on the spatial distribution of members of oceanic, shore, and reef fish groups depending on their origin.

\section{Conclusions}

This study has demonstrated the importance of eddy dynamics in assessing the distribution and abundance of reef fish larvae. The employment of radar remote sensing has provided not only a new perspective on larval ecology but also a viable approach to direct biological sampling and made it possible to interpret the biological response to observations of the dynamics of small-scale flow features. Our results revealed that the evolution of spin-off eddies along the edge of the FC front serve as recruitment mechanism for reef fishes by enhancing the following: 1) longshore dispersal of larvae from coastal origin and 2) cross-frontal exchange of larvae from the adjacent oceanic FC (i.e., from oceanic origin) into settlement sites. Because of the highly dynamic nature of coastal processes and the complexity of larval behavior, re- 

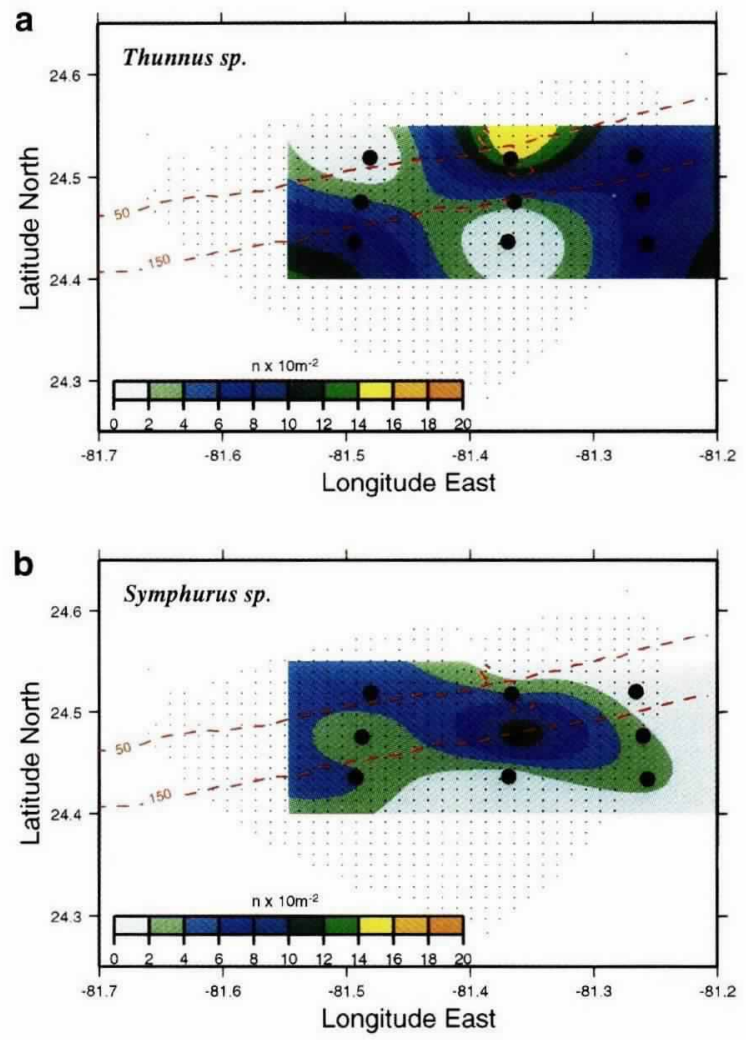

Fig. 4: Spatial distribution of tropical larval fish abundances for representative species of the oceanic group (a) tuna (Thunnus sp.) and of the coastal group (b) tonguefish (Symphyrus sp.).

mote sensing of surface processes provide crucial observations to advance our understanding in variations of larval supply and recruitment rates. By linking remote sensing with other in situ and biological measurements, we will not only identify the influence of nearshore physical forcing (tides, winds, and waves) on reef fish larvae transport, but we will also be able to determine the predictability of small-scale eddies in the Florida Straits and their impact in the coral reef ecosystems.

\section{Acknowledgments}

Numerous personnel, especially Brian Haus, Nick Shay, Dave Jones, and Bill Richards, made this unique study possible by helping with OSCR, ichthyoplankton sampling on the R/V Oregon II, and biological analysis. Special thanks goes to Slavica Nikolic, who produced the graphics. This study was sponsored by the U.S. Coast Guard through South Florida Ocean Pollution Research Center (SFOPRC) and the National Oceanic and Atmospheric Administration under the Southeast Florida Caribbean Recruitment Project (SEFCAR).

\section{References}

Cowen, R.K., J.A. Hare, M.P. Fahay, H.G. Moser, P.E. Smith and L.A. Fuiman, 1993: Beyond hydrography: can physical processes explain larval fish assemblages within the Middle Atlantic Bight? Advances in the early life history of fishes. Bull. Mar. Sci., 53, 567-587.

and S. Sponaugle, 1997: Relationships between early life history traits and recruitment among coral reef fishes. In: Early Life History in Fish Populations. R.C. Chambers and E.A. Trippel, eds. Chapman \& Hall, London, 423-449.

Criales, M.M. and T.N. Lee, 1995: Larval distribution and transport of penaeoid shrimps during the presence of the Tortugas Gyre in May-June 1991. Fish. Bull. US, 93, 471-482.

Graber, H.C., T.N. Lee, B.K. Haus, C.G.H. Rooth, E.J. Williams and L.K. Shay, 1995: Observations of ocean surface currents off the south Florida Keys using an HF Doppler radar. SFOSRC/SEFCAR Pilot Field Study PFS-2: 14 May-13 June 1994. SFOSRC Technical Report, University of Miami, Miami, FL, $175 \mathrm{pp}$.

Haus, B.K., H.C. Graber and L.K. Shay, 1997: Synoptic measurement of dynamic oceanic features. Oceanography, 10, 45-48.

Lee, T.N., 1975: Florida Current spin-off eddies. Deep-Sea Res., 22, 753-765.

- M.E. Clarke, E.J. Williams, A.F. Szmant and T. Berger, 1994: Evolution of the Tortugas gyre and its influence on recruitment in the Florida Keys. Bull. Mar. Sci., 54, 621-646.

, C.G.H. Rooth, E.J. Williams, M.F. McGowan, M.E. Clarke and A.F. Szmant, 1992: Influence of Florida Current, gyres and wind-driven circulation on transport of larvae and recruitment in the Florida Keys coral reefs. Cont. Shelf Res., 12, 971-1002.

Leis, J.M., 1993: Larval fish assemblages near Indo-Pacific coral reefs. Bull. Mar. Sci. 53, 362-392.

Leis, J.M. and S.E. Reader, 1991: Distributional ecology of larval milkfish Chanos chanos (Pisces: Chanidae) in the Lizard Island region. Environ. Biol. Fish., 30, 315-405.

Limouzy-Paris, C.B., M.F. McGowan, W.J. Richards, J.P. Umaran and S.S. Cha, 1994: Diversity of fish larvae in the Florida Keys: results from SEFCAR. Bull. Mar. Sci., 54, 857-870.

, H.C. Graber, D.L. Jones, A. Röpke and W.J. Richards, 1997: Translocation of larval coral reef fishes via submesoscale spin-off eddies from the Florida Current. Bull. Mar. Sci., 60, 966-983.

Milicich, M.J., 1994: Dynamic coupling of reef fish replenishment and oceanographic processes. Mar. Ecol. Prog. Ser., 110, 135-144.

Porch, C.E., 1993: A numerical study of larval retention in the southern Straits of Florida. Ph.D. dissertation, University of Miami, 245 pp.

Richards, S.A., H.P. Possingham and B.J. Noye, 1995: Larval dispersion along a straight coast with tidal currents: complex distribution patterns from a simple model Mar. Ecol. Prog. Ser. 122, 59-71.

Shay, L.K., T.N. Lee, E. Williams, H.C. Graber and C. Rooth, 1997: Vertical structure variations in ocean currents detected by HF radar and an acoustic Doppler current profiler. J. Geophys. Res. In press.

Yeung, C., 1991: The vertical, horizontal, and seasonal distribution and abundance of palinurid and scyllarid lobster phyllosomat larvae in the Florida Keys in relation to the circulation, May 1989-February 1990. M.S. thesis, University of Miami, Miami, FL, $141 \mathrm{pp}$.
... to determine the predictability of smallscale eddies in the

Florida Straits and

their impact in the

coral reef ecosystems. 